\title{
Immunocompetent murine models for the study of glioblastoma immunotherapy
}

\author{
Taemin Oh', Shayan Fakurnejad ${ }^{1}$, Eli T Sayegh ${ }^{1}$, Aaron J Clark², Michael E Ivan², Matthew Z Sun², Michael Safaee², \\ Orin Bloch ${ }^{1}$, Charles D James ${ }^{2}$ and Andrew T Parsa ${ }^{1}$
}

\begin{abstract}
Glioblastoma remains a lethal diagnosis with a 5-year survival rate of less than 10\%. (NEJM 352:987-96, 2005) Although immunotherapy-based approaches are capable of inducing detectable immune responses against tumor-specific antigens, improvements in clinical outcomes are modest, in no small part due to tumor-induced immunosuppressive mechanisms that promote immune escape and immuno-resistance. Immunotherapeutic strategies aimed at bolstering the immune response while neutralizing immunosuppression will play a critical role in improving treatment outcomes for glioblastoma patients. In vivo murine models of glioma provide an invaluable resource to achieving that end, and their use is an essential part of the preclinical workup for novel therapeutics that need to be tested in animal models prior to testing experimental therapies in patients. In this article, we review five contemporary immunocompetent mouse models, GL261 (C57BL/6), GL26 (C57BL/6) CT-2A (C57BL/6), SMA-560 (VM/Dk), and 4C8 (B6D2F1), each of which offer a suitable platform for testing novel immunotherapeutic approaches.
\end{abstract}

Keywords: Glioblastoma, Astrocytoma, Glioma, Immunotherapy, Preclinical, Animal models, Murine, Immune response, Immunosuppression

\section{Introduction}

With a median survival of just 15 months, glioblastoma (GBM) is a notoriously lethal tumor of the central nervous system marked by significant treatment resistance [1]. Standard treatment for patients with GBM is maximum safe resection of tumor followed by radiation with concurrent temozolomide [1]. Glioma immunotherapy, a promising alternative to such aggressive cytotoxic adjuvants, is a highly specific, minimally toxic modality capable of killing tumor cells while sparing normal tissue [2-5]. Immunotherapy in glioma can also activate immune surveillance, and thereby offers the potential for long-term control of this lethal disease [2-6]. However, tumor-induced immunosuppression exists as a considerable barrier to achieving successful immunotherapeutic treatment of GBM and other tumors. GBMs inhibit immune function, systemically as well as within the tumor

\footnotetext{
* Correspondence: taemin.oh@northwestern.edu

'Department of Neurological Surgery, Northwestern University, Feinberg School of Medicine, 676 N. St. Clair St., Suite 2210, Chicago, IL 60611-2922, USA

Full list of author information is available at the end of the article
}

microenvironment, causing many patients to present with impaired cell-mediated immunity [3,5,7]. Implicated mediators of immunosuppression include regulatory $\mathrm{T}$ cells $\left(\mathrm{T}_{\text {regs }}\right)$, myeloid-derived suppressor cells, and M2 macrophages [8]. Tumor heterogeneity [9] and immune escape mechanisms [10] further complicate immunotherapeutic treatment efficacy.

Focused research strategies designed to mitigate immunosuppressive mechanisms could contribute information of critical importance to improving GBM patient outcomes. Preclinical research using immunocompetent mouse models offers a means for studying important interactions between glioma, the immune response, and therapeutics, and for hypothesis-driven evaluation of novel approaches for treating GBM [11]. Here, we present a review on immunocompetent murine glioma models and examine their applications for glioma research, placing specific emphasis on their value to the field of glioma immunotherapy.

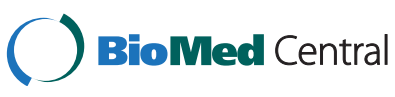

(C) 2014 Oh et al.; licensee BioMed Central Ltd. This is an Open Access article distributed under the terms of the Creative Commons Attribution License (http://creativecommons.org/licenses/by/2.0), which permits unrestricted use, distribution, and reproduction in any medium, provided the original work is properly credited. The Creative Commons Public Domain Dedication waiver (http://creativecommons.org/publicdomain/zero/1.0/) applies to the data made available in this article, unless otherwise stated. 


\section{Murine models for glioma - an overview}

A useful experimental glioma model should have the following features: 1) in vitro sustainability, 2) in vivo recapitulation of glioma features (e.g. invasion and angiogenesis), 3) amenability to genetic manipulation, 4) facile transplantation, 5) reproducible and predictable growth characteristics [12,13]. Histopathology, tumor biology, molecular profiles, and invasiveness are all important characteristics to preserve in order to replicate glioma behavior in vivo.

Two major considerations are important when assessing preclinical models for GBM, the first of which is generation of the tumor itself and the stable transplantable cell lines that follow. GBM tumors can be generated spontaneously, or through induction using chemicals or viruses [14]. Spontaneous tumors, albeit rare and difficult to cultivate without a large host of animals, perhaps best reflect the natural course of human GBM [12,14]. However, for the purpose of increasing expediency and efficiency of time plus effort, tumor induction methods have been more commonly used. Seligman and Shear described the first successful experimental brain tumor in 1939 through intracranial (IC) implantation of 20methylcholanthrene, leading to the development of gliomas and meningeal fibrosarcomas [15]. Viral induction with DNA or RNA viruses has also been widely used for inducing rodent model GBM and has made significant headway over the past few decades [16-19]. However, this approach presents many challenges, among which include potential harm to laboratory personnel, high maintenance requirements, and incomplete tumor penetrance [16-18].

The second consideration is the method of transplantation. Transplantation methods for murine models of glioma can be classified in three ways: 1) implantation of syngeneic primary tumor cells or cultured cell lines into immunocompetent hosts, 2) implantation of human glioma cells into immunocompromised mice (xenografts), or 3) implantation of cells that have been subjected to manipulation of oncogenes or tumor suppressor genes $[12,20]$. Subcutaneous syngeneic transplantation of tumor cells has a long history, initially having been demonstrated over 70years ago [21]. The first report of using athymic (nude) mice as hosts for human tumor cell propagation [22] was followed by the demonstration of human GBM xenograft establishment by Rana et al. [23]. Danks and colleagues described the first transgenic astrocytoma model in 1995 by inducing astrocyte expression of the pro-tumorigenic SV40 large T antigen [24].

Knowledge of model advantages and disadvantages is critical for selecting the best-fit model for achieving study objectives. While there is no single murine model that is appropriate for all types of preclinical research, spontaneous tumors in syngeneic, immunocompetent mouse models provide the most versatile tool for studying immunotherapy and immunosuppression in GBM. Comparatively, xenografts can be modified for the purpose of evaluating GBM immunological treatment modalities, [25-27] but their use is somewhat limited due to a compromised host immune system $[20,28,29]$. Transgenic models that have been engineered to spontaneously develop GBM in immunocompetent hosts have seen increasing use in glioma immunotherapy studies, although these models, in comparison to transplantation models, suffer from reproducibility, latency of tumor formation, and cost $[28,29]$. Transgenics may also result in mixed tumors of diverse histological grades, such that many fail to recapitulate key features of GBM $[29,30]$. Moreover, their genetic alterations can interfere with host immune functions such as lymphopoiesis and clonal expansion, which are important pathways to conserve for immunotherapy research in glioma [20].

In that manner, several syngeneic immunocompetent models are available for preclinical utilization. In the following sections, a brief overview and applications in GBM immunotherapy for each syngeneic model is presented. It should be noted that while each of these tumors arose spontaneously at the time of their discovery, they have since been maintained and experimentally utilized through serial transplantation or generation of transplantable cell lines.

\section{SMA-560-VM/Dk model}

\section{Origins and tumor characteristics}

In 1971, H. Fraser described the first incidence of a spontaneous glioma within the VM mouse strain [31]. Initially, these tumors, which resembled anaplastic astrocytomas, were restricted to in vivo studies only, as tumorigenicity was lost with repeated in vitro passaging of tumor explant cultures [31]. In 1980, Serano and colleagues successfully established five tumor cell lines (P492, P496, P497, P540, P560) following serial transplantation of a spontaneous murine astrocytoma. Cell lines were developed via homogenization of tumor tissue, in vitro culturing, and transplantation into $\mathrm{VM} / \mathrm{Dk}$ mice. Although the P492, P496, and P497 cell lines demonstrated variable tumorigenicity after serial passaging, P540 and P560 maintained tumorigenicity throughout all passages [13]. Median survival for animals bearing SMA-560 tumors has been reported to be approximately 26 days when implanted intracranially with $1 \times 10^{4}$ tumor cells/5 $\mu \mathrm{l}$ [32].

SMA-560 tumor cells provide excellent representation of anaplastic astrocytoma, with low S-100 expression and high expression of glial fibrillary acid protein (GFAP) and glutamine synthetase, thus supporting the astrocytic lineage of derivative tumors $[13,33,34]$. These tumors lack Class II but do express Class I Major Histocompatibility 
Complex (MHC) at low levels, which highlights their potential for antigenic recognition by traditional effector $\mathrm{T}$ cells [35]. Of interest, brain tumors derived from SMA560 cells express transforming growth factor $\beta$ (TGF- $\beta$ ), [35] an immunosuppressive protein known to be secreted by GBM [36]. TGF- $\beta$ expression lends great value to this model, although it has failed to experience widespread use, likely due to its lack of commercial availability, thereby restricting its use to a few academic centers.

\section{Applications in immunotherapy research for GBM}

The SMA-560 model has experienced occasional use, such as in the study by Sampson et al., the results of which showed that manipulation of SMA-560 cells for hyper-secretion of select cytokines, specifically interleukin (IL)-2, IL-4, or tumor necrosis factor $\alpha$, resulted in an increase in median survival of $\mathrm{VM} / \mathrm{Dk}$ mice following IC injection of modified cells $(\mathrm{p}<0.0001)$. SMA-560 cell modification for increased production of IL-3, IL-6, interferon- $\gamma$, Cluster of Differentiation (CD)80, or granulocyte-macrophage colony-stimulating factor, had no significant effect on host survival [35].

Recently, Miller et al. showed that SMA-560 cells transfected to over-express a soluble form of the CD70 ligand reduced tumor growth rate and increased host animal survival. In addition, several long-term survivors from the group injected with CD70-modified cells demonstrated resistance to tumor re-challenge. Finally, the results of this study revealed that improved animal subject outcomes were contingent upon activation of a robust cytotoxic immune response. Immunohistochemical analysis of tumor samples revealed that mice with tumor cells expressing soluble CD70 had greater infiltration of $\mathrm{CD}_{8}{ }^{+} \mathrm{T}$ cells in the tumor periphery, and that depletion of $\mathrm{CD}_{8}{ }^{+} \mathrm{T}$ cells reversed the benefits of soluble CD70 to overall survival [37].

The SMA-560-VM/Dk model has also been used to investigate tumor vaccines. Heimberger et al. pulsed bone marrow-derived dendritic cells (DCs) with SMA-560 homogenate, and administered pulsed DCs to VM/Dk mice prior to IC implantation of SMA-560 cells. Compared to control, mice treated with pulsed DCs demonstrated median survival of $>65$ days versus 25 days, thus representing a $160 \%$ increase in median survival $(p=0.016)$. When surviving immunized mice were rechallenged with tumor 50 days following initial treatment, increased survival again resulted ( $>50$ days), thereby providing evidence for the acquisition of long-lasting antitumor immunity. Both cell-mediated and humoral immunity were found to be involved in the generation of this potent therapeutic response [32]. More recently, Sampson et al. utilized the SMA-560 model to test the efficacy of genetically modified $\mathrm{T}$ cells, which were modified to express chimeric antigen receptors targeting the epidermal growth factor receptor vIII (EGFRvIII), a known glioma antigen. When this was administered to tumor-bearing mice, growth of SMA-560 tumors was abrogated, and treatment conferred resistance to tumor re-challenge [38].

\section{CT-2A; C57BL/6 model}

\section{Origin and tumor characteristics}

Developed specifically for characterizing ganglioside distribution in murine neural tumors, the CT-2A cell line was established by Seyfried et al. in 1992 through chemical induction with 20-methylcholanthrene. Following serial transplantation of tumor fragments into C57BL/6 mice, this syngeneic model for highly malignant, poorly differentiated anaplastic astrocytoma resulted in 100\% mortality within 3-8 weeks [39]. In 2007, MartinezMurrillo et al. standardized techniques for establishing CT-2A tumors from cultured CT-2A cells, as opposed to solid tumors, and demonstrated a survival range of 15-20 days with IC injections of $8 \times 10^{4}$ tumor cells/4 $\mu \mathrm{l}$ [40].

Histologically, CT-2A tumors manifest features of high-grade astrocytomas including pleomorphism and high cellular density, but can undergo malignant transformation with evidence of pseudopalisading necrosis [40]. Tumors are angiogenic, occasionally cystic, and infiltrative, with tumorigenesis rates reported up to $100 \%$ [40-43]. Compared to established glioma cell lines, CT2A cells are significantly more proliferative and invasive ( $\mathrm{p}<0.05)$, [41] but less invasive than other mouse brain tumors [44]. Overall, the CT-2A model is considered to accurately represent several GBM characteristics including intra-tumoral heterogeneity, in vivo migratory patterns, radio-resistance, and chemo-resistance [40].

As recently elucidated by Binello et al., CT-2A tumors also share similarities with neural stem cells, as they form neurospheres when cultured in serum-free media, much like primary human GBMs grown ex vivo, [45] and express stem cell markers such as CD133, Oct, and nestin [41]. Cells expressing Sox9 and Sox10 localize to the periphery of CT-2A tumors [40]. Similarities between CT-2A tumor cells and brain tumor stem cells (BTSCs), which are capable of self-renewal, express CD133, and possess profound tumor-forming capacity, [46-48] may account for their high tumorigenic potential [44]. Phenotypically, the "stemness" of CT-2A tumors manifests as significantly enhanced proliferative and invasive capacity in vitro [41]. Importantly for glioma immunotherapy, however, the consequences of neurosphere formation and culture on CT-2A tumor immunogenicity is currently unknown and requires further investigation.

\section{Applications in immunotherapy research for GBM}

By virtue of its BTSC-like properties, the CT-2A model could provide a resource for studying tumor stem cells in an immunocompetent environment. Due to mounting 
evidence that BTSCs negatively impact overall and progression-free survival, [49] while contributing to treatment resistance in high-grade gliomas, [50,51] therapeutic targeting of BTSCs is a subject of some importance. BTSCs induce immunosuppression by expressing Programmed Death Ligand-1 (PD-L1) and TGF- $\beta 1$, as well as by inhibiting $\mathrm{T}$ cell proliferation, inducing $\mathrm{T}$ cell apoptosis, and enhancing $\mathrm{T}_{\text {reg }}$ function $[52,53]$. While to date, BTSCfocused GBM preclinical research has not been especially active with respect to the development of immunotherapeutic strategies, several groups have recently demonstrated the potential of targeting BTSCs using immunotherapeutic approaches. Morgan et al. tested the efficacy of $\mathrm{T}$ cells genetically engineered to target EGFRvIII on glioma stem cells and found that these lymphocytes induced significant antitumor effects [54]. Brown et al. also found that cytotoxic T lymphocytes (CTLs) engineered to target the IL13R $\alpha 2$ receptor, which can be mutated in GBM, were able to induce tumor regression in xenografts established from stem cells [55]. In non-GBM cancers, passive antibody-mediated approaches and antibody-drug conjugates directed against cancer stem cells have been shown to reduce disease burden [56-59]. Theoretically, BTSCs can be targeted through vaccine therapies, although a potential challenge to this approach concerns BTSC avoidance of immune surveillance [60]. A key research aim, for which the CT-2A model may be well-suited, involves determining how to augment the immunogenicity of $\mathrm{CD}_{133^{+}}$BTSCs, including the identification of novel epitopes to target [60].

CT-2A tumors are also deficient in the phosphatase and tensin homolog (PTEN) protein, leading to dysregulation of the phosphatidylinositol-3 kinase (PI3K) pathway [61]. PTEN mutations also carry clinical significance, and are observed in $40 \%$ of high-grade human gliomas as well as $70 \%$ of glioma cell lines $[61,62]$. PTEN mutations contribute to tumor-induced immunosuppression, and thus the CT-2A model can be utilized to devise strategies for mitigating PTEN deficiency-associated immune effects [63].

\section{GL261; C57BL/6 model}

\section{Origin and tumor characteristics}

The Glioma 261 (GL261) orthotopic model for murine glioma was established in 1970 via chemical induction with methylcholanthrene. Ausman et al. transplanted tumor fragments subcutaneously and intracranially into C57BL/6 mice, with the latter resulting in a median survival of 24-25 days when implanted with $1 \times 10^{5}$ tumor cells/10 $\mu \mathrm{l}[64,65]$. Stable GL261 cell lines for transplantation were constituted in the mid-1990s [65]. Although the GL261 tumors most resemble ependymoblastomas on histology, GL261 tumors closely mimic GBM phenotypes [64]. They stain positively for the GBM marker vimentin [66] and harbor activating mutations of the
K-ras oncogene as well as mutations of the p53 tumor suppressor gene, resulting in high expression of c-myc [65]. Similar genetic derangements have been reported in human gliomas [67-69]. GL261 tumors are partially immunogenic, as they express high levels of MHC I. However, GL261 expression of MHC II, B7-1, and B7-2, the latter two of which are co-stimulatory molecules required for $\mathrm{T}$ cell activation, is limited [65]. Reduced MHC and B7 expression is also characteristic of GBM cell lines and $\mathrm{CD} 133^{+}$BTSCs, which contributes to their escape from immune surveillance [60,70,71].

Tumors established from GL261 cells recapitulate many characteristics of GBM. Tumor formation proceeds through four stages, over a four-week period, following implantation: perivascular organization, proliferation near vasculature, hypoxia through blood vessel degeneration, and neovascularization towards necrotic regions [72]. Histologic analysis reveals pleomorphism, pseudopalisading necrosis, and angiogenesis [72]. While invasive, GL261 tumors are not known to be metastatic [65] and, importantly, these tumors do not spontaneously regress as other murine tumors are known to do on occasion [73].

\section{Applications in immunotherapy research for GBM}

The GL261 murine model has perhaps been the most extensively used for preclinical testing of immunotherapeutic approaches for GBM [74]. Among these studies are: the use of adoptive $\mathrm{T}$ cell transfer to restore and induce long-term immunity [75]; the use of antibodies to improve antitumor $\mathrm{T}$ cell activity via augmentation of costimulatory signaling [76]; and the abrogation of the survival advantage of $\mathrm{T}_{\text {regs }}$ [77]. Gene therapy studies, involving tumor modification for production of inflammatory cytokines (e.g. IL-2) to enhance tumor immunogenicity [78] as well as with IL-12-expressing DNA plasmids to slow tumor growth and stimulate a robust CTL response, [79] have also utilized the GL261 model.

The GL261 model has also been widely used in support of vaccine-based studies. GL261 cells express unique tumor antigens, including HMP/AN2, [80] EphA-2, [81] and GARC-1, [82] and these induce a GL261-specific CTL response. GL261 vaccines, used for pulsing DCs, have been curative and, at times, even preventative of tumor engraftment [83-85]. DC vaccines have also been augmented using adjuvants such as plasmid vectors for IFN- $\gamma$-inducible protein-10 (IP-10) [86] or by antibodymediated depletion of $\mathrm{T}_{\text {regs. }}$ [87] The results of these studies have helped validate GL261 as the model of choice when investigating immunotherapeutic treatment modalities.

The GL261 model has also been used to test experimental methods for mitigating GBM-induced immunosuppression. For instance, in a study by Ueda et al., mice were treated with peptide vaccinations using GL 261- 
specific antigens and a TGF- $\beta$ neutralizing antibody (1D11). Mice receiving both treatments showed 60\% 100 -day survival, in contrast to the $0-20 \%$ survival rates for mice receiving treatments independently. Analysis of animal subjects from this study revealed significantly elevated CTL activity within the lymph nodes and spleens, as well as greater immune cell infiltration, with concurrent reduction of $\mathrm{T}_{\text {regs, }}$ in the brains of the mouse hosts. Overall, treatment was associated with promoting the $\mathrm{Th}_{1}$ phenotype [88].

The GL261 model has also been used for studying the immunosuppressive effects of TGF- $\beta$, which promotes $\mathrm{T}_{\text {reg }}$ activity, on $\mathrm{B}$ and $\mathrm{T}$ cell function $[36,89,90]$. Additional inhibitory mechanisms beyond TGF- $\beta$ can be studied using this model. Given GL261 deficiency in PTEN, GL261 tumors accurately model PI3K pathway dysregulation, which is known to promote glial tumor development [91]. Importantly, PTEN mutations up-regulate expression of PD-L1, a cell surface protein that can be expressed in GBM tumors but not in normal physiologic states [10]. PD-L1 promotes immunosuppression by inducing T lymphocyte apoptosis, [92] and monocytes exposed to $\mathrm{PD}-\mathrm{L}^{+}$gliomas adopt similar expression patterns of PD-L1, leading to increased T cell apoptosis and tumor resistance to immunotherapy $[93,94]$. Devising methods to target and reverse PD-L1-mediated immunosuppression is thus an important objective for optimizing immunotherapies [95].

Since GL261 cells express stem cell markers such as CD133 when grown in serum-free media, these cell subpopulations can be isolated and propagated for experimental use. Importantly, when grown in serum-positive media, GL261 cells differentiate and do not express CD133, [96] as has been similarly reported with primary human GBM cell lines [45]. Isolation of CD133 ${ }^{+}$GL261 cells appears to increase tumorigenicity, as even IC implantation of $\mathrm{CD}_{133^{+}}$GL261 cells at small volumes ( 100 cells) leads to tumor formation and GL261 neurosphere formation is also greater when culturing $\mathrm{CD}_{133}{ }^{+}$cells in serum-free media [96]. Thus, as is the case for the CT-2A model, GL261 tumors may find use for studying BTSCs and immunosuppression. However, one potentially important consideration to this is that GL261 stem cells appear to enhance tumor immunogenicity. As demonstrated by Pellegatta et al., DCs pulsed with tumor lysates from GL261 neurospheres, as opposed to normal GL261 cells, generated a more robust $\mathrm{T}$ cell and antitumor immune response [97]. More recently, $\mathrm{Xu}$ et al. lent further evidence to this by showing that immunotherapy with DCs pulsed with GL261 stem cell lysates or DCs pulsed with GL261 lysates were able to prevent tumor formation in $37.5 \%$ and $0 \%$ of mice, respectively, and induced a significant CTL response [98].
Despite the extensive information yield from using the GL261 cells, an inherent disadvantage of this model is its moderate immunogenicity which may complicate interpretation of experimental data [65]. Reduced immunogenicity can confound evaluation of responses to immunotherapy, and extrapolation of results to the clinical setting, as GBM is known to be an immuneprivileged tumor that evades host immune recognition [99]. Nevertheless, the GL261 system presents one of the best characterized syngeneic, immunocompetent models, and it is likely that this model will continue to see extensive use in immunotherapy preclinical research.

\section{GL26; C57BL/6 model}

\section{Origin and tumor characteristics}

The less commonly utilized GL26 glioma cell line closely resembles GL261, and was first chemically induced by Sugiura in 1969 [64]. Much like its GL261 analog, GL26 tumors bear greatest histologic resemblance to ependymoblastomas. However, they differ slightly in that GL26 tumors tend to demonstrate greater necrosis and vascularity in addition to being more hemorrhagic [64]. Overall, GL26 gliomas possess characteristic GBM features that lend well to GBM research: they stain positive for vimentin and exhibit cellular pleomorphism, hypercellularity, nuclear atypical, and inflammation [66]. Although GL26 cells express Class I MHC antigens, Class II MHC antigens are undetectable [100]. Median survival following IC tumor implantation of $2 \times 10^{4}$ tumor cells/0.5 $\mu \mathrm{l}$ is 31 days [66].

\section{Applications in immunotherapy for GBM}

The GL26; C57BL/6 model has been utilized to study several immunotherapeutic approaches and, while it has not seen as extensive use as GL261, there is evidence to suggest that this model can prove invaluable to the study of immunotherapy. GL26 tumors express melanomaassociated antigens (MAAs) "gp100" and "tyrosinaserelated protein 2 (TRP-2)," both of which can be immunogenically targeted for CTL-mediated destruction. Prins et al., for example, employed this strategy to great effect by vaccinating mice with MAA-pulsed DCs, which led to a robust antitumor immune response and significantly prolonged survival [101]. Alternatively, Kim and colleagues have shown similar antitumor efficacy with the administration of genetically engineered IL-12-expressing DCs pulsed with GL26 tumor lysates [102].

Other strategies tested with this model include $\mathrm{T}_{\text {reg }}$ depletion using PC61, and antibody directed against CD25, which is one of the primary markers for $\mathrm{T}_{\text {regs }}$. Curtin et al. found that, although PC61 was unable to induce immunologic memory against tumors and prevented the expansion of tumor-specific $\mathrm{T}$ lymphocytes, it did inhibit tumor growth, dramatically reduce tumor 
infiltration with $\mathrm{T}_{\text {regs }}$, and prolong overall survival in the context of low tumor burden [103]. The benefits of combinatorial chemo-immunotherapy consisting of pulsed DCs and temozolomide have also been investigated. When Park et al. treated tumor-bearing mice with lowdose temozolomide and DCs transfected for survivin, an anti-apoptotic highly expressed in gliomas, prolonged survival was seen and this was due to increased crosspriming of tumor-specific T cells [104]. Another group similarly utilized low-dose temozolomide and DCs pulsed with tumor lysates to show increased cross-priming, immune infiltration, and survival, thereby highlighting the potential promise for this therapeutic approach [105].

\section{C8; B6D2F1 model}

\section{Origin and tumor characteristics}

Weiner et al. developed the 4C8-B6D2F1 model to address shortcomings observed with other murine glial tumors [106]. The 4C8 tumor was established from clonal cell lines of a glial tumor known as MOCH-1, derived from a transgenic mouse. This approach should, in fact, be generalizable to the development of dozens of syngeneic, immunocompetent engraftment models, using tumor cells from the many brain tumor transgenic mouse models that have been created over the past 2 decades of genetically engineered mouse model research. In contrast to $\mathrm{MOCH}-1$, which strongly resembles
GBM, 4C8 cells adopt oligodendrocytic characteristics in vitro but convert to $\mathrm{GFAP}^{+}$astrocytes when exposed to serum [107]. IC implantation into B6D2F1 mice produces pleomorphic, highly cellular tumors, with extensive invasion into ventricles and meninges [106]. B6D2F1 tumors also express components of MHC I and II molecules [108]. Overall, mice bearing B6D2F1 tumors have demonstrated a mean survival of approximately 51 days when intracranially injected with $1 \times 10^{6}$ cells/5 $\mu \mathrm{l}[106]$.

\section{Applications in immunotherapy research for GBM}

One application of this model has been for the analysis of effects from treating tumors with cationic liposomal non-coding plasmid DNA complexes (EV-CLDC), which demonstrated inhibition of tumor growth $(p<0.0001)$ [108]. In addition, intratumoral injections of vaccines with herpes simplex viruses, engineered to secrete IL-12, have been shown to promote significant anti-tumor activity, with immune cell infiltration, and minimal toxicity $[109,110]$. As a relatively new model, however, additional study is needed to reveal the full range of this model's applications.

\section{Summary and conclusion}

Animal models have been indispensable for the study of gliomagenesis, glioma progression, and experimental

Table 1 Immuno-competent syngeneic murine models of glioma

\begin{tabular}{|c|c|c|c|c|c|}
\hline Cell line & Host & Induction & Histology & $\begin{array}{l}\text { Specific and potential applications in } \\
\text { immunotherapy }\end{array}$ & Refs \\
\hline \multirow[t]{3}{*}{$P 560$} & VM/Dk & Spontaneous & Anaplastic Astrocytoma & - Vaccine studies (e.g. DC) & $13,31-38$ \\
\hline & & & & - Gene therapy studies (e.g. IL-2, CD70) & \\
\hline & & & & $\begin{array}{l}\text { - Reversal of immunosuppression in glioma } \\
\text { (e.g. TGF- } \beta \text { ) }\end{array}$ & \\
\hline \multirow[t]{2}{*}{$\mathrm{CT}-2 \mathrm{~A}$} & C57BL/6 & Chemical & Anaplastic Astrocytoma & - Tumor stem cells (BTSCs) & $39-63$ \\
\hline & & & & $\begin{array}{l}\text { - Reversal of immunosuppression in glioma } \\
\text { (e.g. TGF- } \beta \text {, PTEN) }\end{array}$ & \\
\hline \multirow[t]{5}{*}{ GL261 } & C57BL/6 & Chemical & GBM/Ependymoblastoma & - Tumor stem cells (BTSCs) & $10,35,60,64-99$ \\
\hline & & & & - Vaccine studies (e.g. dendritic cells) & \\
\hline & & & & - Gene therapy studies (e.g. IL-2) & \\
\hline & & & & - Adoptive $T$ cell, antibody, and $\mathrm{T}_{\text {reg }}$ depletion studies & \\
\hline & & & & $\begin{array}{l}\text { - Reversal of immunosuppression in glioma } \\
\text { (e.g. TGF- } \beta \text {, PTEN) }\end{array}$ & \\
\hline \multirow[t]{4}{*}{ GL26 } & C57BL/6 & Chemical & GBM/Ependymoblastoma & - Vaccine studies (e.g. dendritic cells) & $64,66,100-105$ \\
\hline & & & & - Gene therapy studies (e.g. IL-12) & \\
\hline & & & & - $T_{\text {reg }}$ depletion studies & \\
\hline & & & & • Chemo-immunotherapy & \\
\hline \multirow[t]{2}{*}{$4 C 8$} & B6D2F1 & Transgenic & Oligodendroglioma, Astrocytoma & - Vaccine studies (e.g. HSV) & $106-110$ \\
\hline & & & & - Gene therapy studies (e.g. plasmids) & \\
\hline
\end{tabular}


therapies. Transplant models offer the convenience of predictable tumor location and growth rate while facilitating the study of interactions between gliomas and the host immune system [111]. However, it is important to note that all animal models have certain deficiencies that place limitations on their use, [20] and knowledge of these, as well as model strengths, is essential for obtaining preclinical results that are meaningful for clinical translation [20].

The five syngeneic immunocompetent murine models reviewed, as summarized in Table 1, recapitulate certain histologic and biological characteristics of human astrocytomas and GBM, and their use of immunocompetent, syngeneic hosts make them well-suited for studying glioma immunology and a range of experimental immunotherapies. Preclinical findings from these murine models have already been translated to clinical trials in human glioma patients. For example, immunotherapeutic treatments utilizing DC vaccines pulsed with whole tumor homogenate [112] or tumor-specific peptides, such as for EGFRvIII, [113-115] owe their translational origins to successful studies using the GL261 model [84,116-119]. Other clinical trials for targets such as TGF- $\beta[120,121]$ and gene therapeutic approaches [122] also have origins in preclinical studies using the SMA-560 [123] and GL261 models, $[124,125]$ respectively.

Contemporary literature indicates that the GL261 model has been most frequently used. However, further research using SMA-560, CT-2A, GL26, and 4C8 tumors seems likely to reveal additional glioma immunotherapy applications for these models as well. Given the promise of immunotherapy as part of a multimodal treatment paradigm for GBM, such in vivo models will continue to prove invaluable in the future.

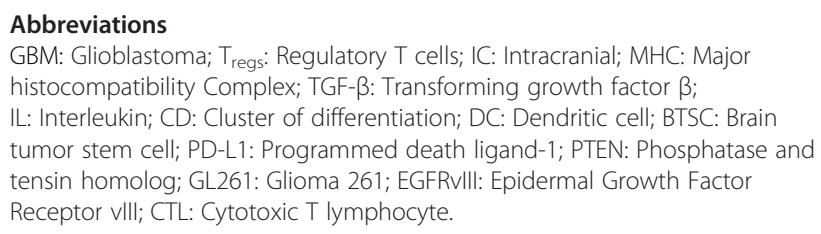

\section{Abbreviations}

GBM: Glioblastoma; $T_{\text {regs: }}$ Regulatory T cells; IC: Intracranial; MHC: Major histocompatibility Complex; TGF- $\beta$ : Transforming growth factor $\beta$; IL: Interleukin; CD: Cluster of differentiation; DC: Dendritic cell; BTSC: Brain tumor stem cell; PD-L1: Programmed death ligand-1; PTEN: Phosphatase and tensin homolog; GL261: Glioma 261; EGFRvIll: Epidermal Growth Factor Receptor vIll; CTL: Cytotoxic T lymphocyte.

\section{Competing interests}

The author(s) declare that they have no competing interests to report.

\section{Authors' contributions}

TO participated in the design and coordination of the study, and wrote the manuscript. SF and ES helped draft the manuscript and collect relevant information. AC, MI, MZS, and MS were substantially involved in the design process, provided critical review of the manuscript, and assisted in the analysis and interpretation of the data. OB, CDJ, and ATP were instrumental in the coordination of the study and provided critical insight, direction, and revisions throughout the drafting process. ATP also spearheaded the study concept and design. All authors read and approved the final manuscript.

\section{Acknowledgements}

Dr. Ivan is funded by the National Research Education Foundation through the American Association of Neurological Surgeons. M.Z. Sun and E.T. Sayegh are Howard Hughes Medical Institute Medical Research Fellows. M. Safaee was supported by a grant from the Doris Duke Charitable Foundation. This work was supported by the Reza and Georgianna Khatib Endowed Chair in Skull Base Tumor Surgery at UCSF, and the Michael J. Marchese Professor and Chair at Northwestern University.

\section{Author details}

${ }^{1}$ Department of Neurological Surgery, Northwestern University, Feinberg School of Medicine, 676 N. St. Clair St., Suite 2210, Chicago, IL 60611-2922, USA. ${ }^{2}$ Department of Neurological Surgery, University of California, San Francisco, 505 Parnassus Ave., Room 779M, San Francisco, CA 94143-0112, USA.

Received: 30 January 2014 Accepted: 16 April 2014

Published: 29 April 2014

\section{References}

1. Stupp R, Mason WP, van den Bent MJ, Weller M, Fisher B, Taphoorn MJ, Belanger K, Brandes AA, Marosi C, Bogdahn U, Curschmann J, Janzer RC, Ludwin SK, Gorlia T, Allgeier A, Lacombe D, Cairncross JG, Eisenhauer E, Mirimanoff RO, European Organisation for Research and Treatment of Cancer Brain Tumor and Radiotherapy Groups, National Cancer Institute of Canada Clinical Trials Group: Radiotherapy plus concomitant and adjuvant temozolomide for glioblastoma. N Engl J Med 2005, 352:987-996.

2. Topalian SL, Weiner GJ, Pardoll DM: Cancer immunotherapy comes of age. J Clin Oncol 2011, 29:4828-4836.

3. Reardon DA, Wucherpfennig KW, Freeman G, Wu CJ, Chiocca EA, Wen PY, Curry WT Jr, Mitchell DA, Fecci PE, Sampson JH, Dranoff G: An update on vaccine therapy and other immunotherapeutic approaches for glioblastoma. Expert Rev Vaccines 2013, 12:597-615.

4. Bovenberg MS, Degeling MH, Tannous BA: Cell-based immunotherapy against gliomas: from bench to bedside. Mol Ther 2013, 21:1297-1305.

5. Schreiber RD, Old $L$, Smyth MJ: Cancer immunoediting: integrating immunity's roles in cancer suppression and promotion. Science 2011, 331:1565-1570

6. Aguilar LK, Arvizu M, Aguilar-Cordova E, Chiocca EA: The spectrum of vaccine therapies for patients with glioblastoma multiforme. Curr Treat Options Oncol 2012, 13:437-450.

7. Mohme M, Neidert MC, Regli L, Weller M, Martin R: Immunological challenges for peptide-based immunotherapy in glioblastoma. Cancer Treat Rev 2014, 40:248-258.

8. Heimberger $A B$, Sampson JH: Immunotherapy coming of age: what will it take to make it standard of care for glioblastoma? Neuro Oncol 2011, 13:3-13.

9. Denysenko T, Gennero L, Roos MA, Melcarne A, Juenemann C, Faccani G, Morra I, Cavallo G, Reguzzi S, Pescarmona G, Ponzetto A: Glioblastoma cancer stem cells: heterogeneity, microenvironment and related therapeutic strategies. Cell Biochem Funct 2010, 28:343-351.

10. Parsa AT, Waldron JS, Panner A, Crane CA, Parney IF, Barry JJ, Cachola KE, Murray JC, Tihan T, Jensen MC, Mischel PS, Stokoe D, Pieper RO: Loss of tumor suppressor PTEN function increases B7-H1 expression and immunoresistance in glioma. Nat Med 2007, 13:84-88.

11. Barth RF, Kaur B: Rat brain tumor models in experimental neuro-oncology: the C6, 9L, T9, RG2, F98, BT4C, RT-2 and CNS-1 gliomas. J Neurooncol 2009, 94:299-312.

12. Peterson DL, Sheridan PJ, Brown WE Jr: Animal models for brain tumors: historical perspectives and future directions. J Neurosurg 1994, 80:865-876 
13. Serano RD, Pegram CN, Bigner DD: Tumorigenic cell culture lines from a spontaneous VM/Dk murine astrocytoma (SMA). Acta Neuropathol 1980, 51:53-64.

14. Hewitt HB, Blake ER, Walder AS: A critique of the evidence for active host defence against cancer, based on personal studies of 27 murine tumours of spontaneous origin. Br J Cancer 1976, 33:241-259.

15. Seligman AM, Shear M, Alexander L: Studies in Carcinogenesis: VIII. Experimental Production of Brain Tumors in Mice with Methylcholanthrene. Am J Cancer 1939, 37:364-395.

16. Sonabend AM, Ulasov IV, Lesniak MS: Emerging role of new transgenic mouse models in glioma research. Expert Rev Anticancer Ther 2007, 7:S7-S13.

17. Hambardzumyan D, Parada LF, Holland EC, Charest A: Genetic modeling of gliomas in mice: new tools to tackle old problems. Glia 2011, 59:1155-1168

18. Huse JT, Holland EC: Genetically engineered mouse models of brain cancer and the promise of preclinical testing. Brain Pathol 2009, 19:132-143.

19. Chow LM, Baker SJ: Capturing the molecular and biological diversity of high-grade astrocytoma in genetically engineered mouse models. Oncotarget 2012, 3:67-77.

20. Sughrue ME, Yang I, Kane AJ, Rutkowski MJ, Fang S, James CD, Parsa AT: Immunological considerations of modern animal models of malignant primary brain tumors. J Transl Med 2009, 7:84.

21. Zimmerman HM, Arnold H: Experimental brain tumors I. Tumors produced with methylcholanthrene. Cancer Res 1941, 1:919-938.

22. Pantelouris EM: Absence of thymus in a mouse mutant. Nature 1968, 217:370-371.

23. Rana MW, Pinkerton $H$, Thornton H, Nagy D: Heterotransplantation of human glioblastoma multiforme and meningioma to nude mice. Proc Soc Exp Biol Med 1977, 155:85-88.

24. Danks RA, Orian JM, Gonzales MF, Tan SS, Alexander B, Mikoshiba K, Kaye $\mathrm{AH}$ : Transformation of astrocytes in transgenic mice expressing SV40 $\mathrm{T}$ antigen under the transcriptional control of the glial fibrillary acidic protein promoter. Cancer Res 1995, 55:4302-4310.

25. Ahmed N, Salsman VS, Kew Y, Shaffer D, Powell S, Zhang YJ, Grossman RG, Heslop HE, Gottschalk S: HER2-specific T cells target primary glioblastoma stem cells and induce regression of autologous experimental tumors. Clin Cancer Res 2010, 16:474-485.

26. Balyasnikova IV, Ferguson SD, Sengupta S, Han Y, Lesniak MS: Mesenchymal stem cells modified with a single-chain antibody against EGFRvlll successfully inhibit the growth of human xenograft malignant glioma. PLoS One 2010, 5:e9750,

27. Ohno M, Natsume A, Ichiro Iwami K, Iwamizu H, Noritake $K$, Ito D, Toi Y, Ito M, Motomura K, Yoshida J, Yoshikawa K, Wakabayashi T: Retrovirally engineered T-cell-based immunotherapy targeting type III variant epidermal growth factor receptor, a glioma-associated antigen. Cancer Sci 2010, 101:2518-2524.

28. Chen L, Zhang Y, Yang J, Hagan JP, Li M: Vertebrate animal models of glioma: understanding the mechanisms and developing new therapies. Biochim Biophys Acta 1836, 2013:158-165.

29. Rankin SL, Zhu G, Baker SJ: Review: insights gained from modelling high-grade glioma in the mouse. Neuropathol Appl Neurobiol 2012, 38:254-270

30. Reilly KM, Jacks T: Genetically engineered mouse models of astrocytoma: GEMs in the rough? Semin Cancer Biol 2001, 11:177-191.

31. Fraser H: Astrocytomas in an inbred mouse strain. J Pathol 1971, 103:266-270.

32. Heimberger AB, Crotty LE, Archer GE, McLendon RE, Friedman A, Dranoff G, Bigner DD, Sampson JH: Bone marrow-derived dendritic cells pulsed with tumor homogenate induce immunity against syngeneic intracerebral glioma. J Neuroimmunol 2000, 103:16-25.

33. Pilkington GJ, Darling $J$, Lantos PL, Thomas DG: Cell lines (VMDk) derived from a spontaneous murine astrocytoma. Morphological and immunocytochemical characterization. J Neurol Sci 1983, 62:115-139.

34. Pilkington GJ, Lantos PL, Darling JL, Thomas DG: Three cell lines from a spontaneous murine astrocytoma show variation in astrocytic differentiation. Neurosci Lett 1982, 34:315-320.

35. Sampson JH, Ashley DM, Archer GE, Fuchs HE, Dranoff G, Hale LP, Bigner DD: Characterization of a spontaneous murine astrocytoma and abrogation of its tumorigenicity by cytokine secretion. Neurosurgery 1997, 41:1365-1372. discussion 1372-1363.

36. Bodmer S, Strommer K, Frei K, Siepl C, de Tribolet N, Heid I, Fontana A: Immunosuppression and transforming growth factor-beta in glioblastoma: Preferential production of transforming growth factor-beta $2 . J$ Immunol 1989, 143:3222-3229.

37. Miller J, Eisele G, Tabatabai G, Aulwurm S, von Kurthy G, Stitz L, Roth P, Weller M: Soluble CD70: a novel immunotherapeutic agent for experimental glioblastoma. J Neurosurg 2010, 113:280-285.

38. Sampson JH, Choi BD, Sanchez-Perez L, Suryadevara CM, Snyder DJ, Flores CT, Schmittling RJ, Nair SK, Reap EA, Norberg PK, Herndon JE 2nd, Kuan CT, Morgan RA, Rosenberg SA, Johnson LA: EGFRvIll mCAR-Modified T-Cell Therapy Cures Mice with Established Intracerebral Glioma and Generates Host Immunity against Tumor-Antigen Loss. Clin Cancer Res 2014, 20:972-984.

39. Seyfried TN, el-Abbadi M, Roy ML: Ganglioside distribution in murine neural tumors. Mol Chem Neuropathol 1992, 17:147-167.

40. Martinez-Murillo R, Martinez A: Standardization of an orthotopic mouse brain tumor model following transplantation of CT-2A astrocytoma cells. Histol Histopathol 2007, 22:1309-1326.

41. Binello E, Qadeer ZA, Kothari HP, Emdad L, Germano IM: Stemness of the CT-2A Immunocompetent Mouse Brain Tumor Model: Characterization In Vitro. J Cancer 2012, 3:166-174

42. Abate LE, Mukherjee P, Seyfried TN: Gene-linked shift in ganglioside distribution influences growth and vascularity in a mouse astrocytoma. J Neurochem 2006, 98:1973-1984.

43. Mukherjee $P$, Abate LE, Seyfried TN: Antiangiogenic and proapoptotic effects of dietary restriction on experimental mouse and human brain tumors. Clin Cancer Res 2004, 10:5622-5629.

44. Shelton LM, Mukherjee P, Huysentruyt LC, Urits I, Rosenberg JA, Seyfried TN: A novel pre-clinical in vivo mouse model for malignant brain tumor growth and invasion. J Neurooncol 2010, 99:165-176.

45. Lee J, Kotliarova S, Kotliarov Y, Li A, Su Q, Donin NM, Pastorino S, Purow BW, Christopher N, Zhang W, Park JK, Fine HA: Tumor stem cells derived from glioblastomas cultured in bFGF and EGF more closely mirror the phenotype and genotype of primary tumors than do serum-cultured cell lines. Cancer Cell 2006, 9:391-403.

46. Qiang L, Yang Y, Ma YJ, Chen FH, Zhang LB, Liu W, Qi Q, Lu N, Tao L, Wang $X T$, You QD, Guo QL: Isolation and characterization of cancer stem like cells in human glioblastoma cell lines. Cancer Lett 2009, 279:13-21.

47. Yuan X, Curtin J, Xiong Y, Liu G, Waschsmann-Hogiu S, Farkas DL, Black KL, Yu JS: Isolation of cancer stem cells from adult glioblastoma multiforme. Oncogene 2004, 23:9392-9400.

48. Singh SK, Hawkins C, Clarke ID, Squire JA, Bayani J, Hide T, Henkelman RM, Cusimano MD, Dirks PB: Identification of human brain tumour initiating cells. Nature 2004, 432:396-401

49. Zeppernick F, Ahmadi R, Campos B, Dictus C, Helmke BM, Becker N, Lichter P, Unterberg A, Radlwimmer B, Herold-Mende CC: Stem cell marker CD133 affects clinical outcome in glioma patients. Clin Cancer Res 2008, 14:123-129.

50. Eramo A, Ricci-Vitiani L, Zeuner A, Pallini R, Lotti F, Sette G, Pilozzi E, Larocca LM, Peschle C, De Maria R: Chemotherapy resistance of glioblastoma stem cells. Cell Death Differ 2006, 13:1238-1241.

51. Blazek ER, Foutch $J$, Maki G: Daoy medulloblastoma cells that express CD133 are radioresistant relative to CD133- cells, and the CD133+ sector is enlarged by hypoxia. Int J Radiat Oncol Biol Phys 2007, 67:1-5.

52. Wei J, Barr J, Kong LY, Wang Y, Wu A, Sharma AK, Gumin J, Henry V, Colman $H$, Sawaya R, Lang FF, Heimberger AB: Glioma-associated cancer-initiating cells induce immunosuppression. Clin Cancer Res 2010, 16:461-473.

53. Wei J, Barr J, Kong LY, Wang Y, Wu A, Sharma AK, Gumin J, Henry V, Colman $H$, Priebe W, Sawaya R, Lang FF, Heimberger AB: Glioblastoma cancerinitiating cells inhibit T-cell proliferation and effector responses by the signal transducers and activators of transcription 3 pathway. Mol Cancer Ther 2010, 9:67-78

54. Morgan RA, Johnson LA, Davis JL, Zheng Z, Woolard KD, Reap EA, Feldman SA, Chinnasamy N, Kuan CT, Song H, Zhang W, Fine HA, Rosenberg SA: Recognition of glioma stem cells by genetically modified $T$ cells targeting EGFRvIll and development of adoptive cell therapy for glioma. Hum Gene Ther 2012, 23:1043-1053.

55. Brown CE, Starr R, Aguilar B, Shami AF, Martinez C, D'Apuzzo M, Barish ME, Forman SJ, Jensen MC: Stem-like tumor-initiating cells isolated from 
IL13Ralpha2 expressing gliomas are targeted and killed by IL13-zetakineredirected T Cells. Clin Cancer Res 2012, 18:2199-2209.

56. Schatton T, Murphy GF, Frank NY, Yamaura K, Waaga-Gasser AM, Gasser M, Zhan Q, Jordan S, Duncan LM, Weishaupt C, Fuhlbrigge RC, Kupper TS, Sayegh MH, Frank MH: Identification of cells initiating human melanomas. Nature 2008, 451:345-349.

57. Jin L, Hope KJ, Zhai Q, Smadja-Joffe F, Dick JE: Targeting of CD44 eradicates human acute myeloid leukemic stem cells. Nat Med 2006, 12:1167-1174

58. Krause DS, Lazarides K, von Andrian UH, Van Etten RA: Requirement for CD44 in homing and engraftment of BCR-ABL-expressing leukemic stem cells. Nat Med 2006, 12:1175-1180.

59. Smith LM, Nesterova A, Ryan MC, Duniho S, Jonas M, Anderson M, Zabinsk RF, Sutherland MK, Gerber HP, Van Orden KL, Moore PA, Ruben SM, Carter PJ: CD133/prominin-1 is a potential therapeutic target for antibody-drug conjugates in hepatocellular and gastric cancers. Br J Cancer 2008, 99:100-109.

60. Wu A, Wiesner S, Xiao J, Ericson K, Chen W, Hall WA, Low WC, Ohlfest JR: Expression of MHC I and NK ligands on human CD133+ glioma cells: possible targets of immunotherapy. I Neurooncol 2007, 83:121-131.

61. Marsh J, Mukherjee P, Seyfried TN: Akt-dependent proapoptotic effects of dietary restriction on late-stage management of a phosphatase and tensin homologue/tuberous sclerosis complex 2-deficient mouse astrocytoma. Clin Cancer Res 2008, 14:7751-7762.

62. Ishii N, Maier D, Merlo A, Tada M, Sawamura Y, Diserens AC, Van Meir EG Frequent co-alterations of TP53, p16/CDKN2A, p14ARF, PTEN tumor suppressor genes in human glioma cell lines. Brain Pathol 1999, 9:469-479.

63. Waldron JS, Yang I, Han S, Tihan T, Sughrue ME, Mills SA, Pieper RO, Parsa AT: Implications for immunotherapy of tumor-mediated T-cell apoptosis associated with loss of the tumor suppressor PTEN in glioblastoma. J Clin Neurosci 2010, 17:1543-1547.

64. Ausman Jl, Shapiro WR, Rall DP: Studies on the chemotherapy of experimental brain tumors: development of an experimental model. Cancer Res 1970, 30:2394-2400.

65. Szatmari T, Lumniczky K, Desaknai S, Trajcevski S, Hidvegi EJ, Hamada H, Safrany G: Detailed characterization of the mouse glioma 261 tumor model for experimental glioblastoma therapy. Cancer Sci 2006, 97:546-553.

66. Candolfi M, Curtin JF, Nichols WS, Muhammad AG, King GD, Pluhar GE, McNiel EA, Ohlfest JR, Freese AB, Moore PF, Lerner J, Lowenstein PR, Castro MG: Intracranial glioblastoma models in preclinical neuro-oncology: neuropathological characterization and tumor progression. J Neurooncol 2007, 85:133-148.

67. Sidransky D, Mikkelsen T, Schwechheimer K, Rosenblum ML, Cavanee W, Vogelstein B: Clonal expansion of p53 mutant cells is associated with brain tumour progression. Nature 1992, 355:846-847.

68. Trent J, Meltzer P, Rosenblum M, Harsh G, Kinzler K, Mashal R, Feinberg A, Vogelstein B: Evidence for rearrangement, amplification, and expression of c-myc in a human glioblastoma. Proc Natl Acad Sci U S A 1986, 83:470-473.

69. Gururaj AE, Gibson L, Panchabhai S, Bai M, Manyam G, Lu Y, Latha K, Rojas ML, Hwang Y, Liang S, Bogler O: Access to the nucleus and functional association with c-Myc is required for the full oncogenic potential of DeltaEGFR/EGFRvIll. J Biol Chem 2013, 288:3428-3438.

70. Zagzag D, Salnikow K, Chiriboga L, Yee H, Lan L, Ali MA, Garcia R, Demaria S, Newcomb EW: Downregulation of major histocompatibility complex antigens in invading glioma cells: stealth invasion of the brain. Lab Invest 2005, 85:328-341.

71. Anderson RC, Anderson DE, Elder JB, Brown MD, Mandigo CE, Parsa AT, Goodman RR, McKhann GM, Sisti MB, Bruce JN: Lack of B7 expression, not human leukocyte antigen expression, facilitates immune evasion by human malignant gliomas. Neurosurgery 2007, 60:1129-1136. discussion 1136

72. Zagzag D, Amirnovin R, Greco MA, Yee H, Holash J, Wiegand SJ, Zabski S, Yancopoulos GD, Grumet M: Vascular apoptosis and involution in gliomas precede neovascularization: a novel concept for glioma growth and angiogenesis. Lab Invest 2000, 80:837-849.

73. Vince GH, Bendszus M, Schweitzer T, Goldbrunner RH, Hildebrandt S, Tilgner J, Klein R, Solymosi L, Christian Tonn J, Roosen K: Spontaneous regression of experimental gliomas-an immunohistochemical and MRI study of the C6 glioma spheroid implantation model. Exp Neurol 2004, 190:478-485.

74. Maes W, Van Gool SW: Experimental immunotherapy for malignant glioma: lessons from two decades of research in the GL261 model. Cancer Immunol Immunother 2011, 60:153-160.

75. Plautz GE, Touhalisky JE, Shu S: Treatment of murine gliomas by adoptive transfer of ex vivo activated tumor-draining lymph node cells. Cell Immunol 1997, 178:101-107.

76. Kim JA, Averbook BJ, Chambers K, Rothchild K, Kjaergaard J, Papay R, Shu S: Divergent effects of 4-1BB antibodies on antitumor immunity and on tumor-reactive T-cell generation. Cancer Res 2001, 61:2031-2037.

77. Fecci PE, Ochiai H, Mitchell DA, Grossi PM, Sweeney AE, Archer GE, Cummings T, Allison JP, Bigner DD, Sampson JH: Systemic CTLA-4 blockade ameliorates glioma-induced changes to the CD4+ $\mathrm{T}$ cell compartment without affecting regulatory T-cell function. Clin Cancer Res 2007, 13:2158-2167.

78. Lichtor T, Glick RP, Kim TS, Hand R, Cohen EP: Prolonged survival of mice with glioma injected intracerebrally with double cytokine-secreting cells. J Neurosurg 1995, 83:1038-1044.

79. Keke F, Hongyang Z, Hui Q, Jixiao L, Jian C: A combination of flk1-based DNA vaccine and an immunomodulatory gene (IL-12) in the treatment of murine cancer. Cancer Biother Radiopharm 2004, 19:649-657.

80. Paul AK, Ciesielski MJ, Sajijad M, Wang X, Ferrone S, Abdel-Nabi H, Fenstermaker RA: Expression of HMP/AN2, a melanoma associated antigen, in murine cerebral gliomas: potential for radioimmunotargeting. J Neurooncol 2009, 94:21-30.

81. Hatano M, Kuwashima N, Tatsumi T, Dusak JE, Nishimura F, Reilly KM, Storkus WJ, Okada H: Vaccination with EphA2-derived T cell-epitopes promotes immunity against both EphA2-expressing and EphA2-negative tumors. J Transl Med 2004, 2:40.

82. lizuka Y, Kojima H, Kobata T, Kawase T, Kawakami Y, Toda M: Identification of a glioma antigen, GARC-1, using cytotoxic T lymphocytes induced by HSV cancer vaccine. Int J Cancer 2006, 118:942-949.

83. Ciesielski MJ, Apfel L, Barone TA, Castro CA, Weiss TC, Fenstermaker RA: Antitumor effects of a xenogeneic survivin bone marrow derived dendritic cell vaccine against murine GL261 gliomas. Cancer Immunol Immunother 2006, 55:1491-1503.

84. Ni HT, Spellman SR, Jean WC, Hall WA, Low WC: Immunization with dendritic cells pulsed with tumor extract increases survival of mice bearing intracranial gliomas. J Neurooncol 2001, 51:1-9.

85. Pellegatta S, Poliani PL, Corno D, Grisoli M, Cusimano M, Ubiali F, Baggi F, Bruzzone MG, Finocchiaro G: Dendritic cells pulsed with glioma lysates induce immunity against syngeneic intracranial gliomas and increase survival of tumor-bearing mice. Neurol Res 2006, 28:527-531.

86. Jiang XB, Lu XL, Hu P, Liu RE: Improved therapeutic efficacy using vaccination with glioma lysate-pulsed dendritic cells combined with IP-10 in murine glioma. Vaccine 2009, 27:6210-6216.

87. Maes W, Rosas GG, Verbinnen B, Boon L, De Vleeschouwer S, Ceuppens JL, Van Gool SW: DC vaccination with anti-CD25 treatment leads to long-term immunity against experimental glioma. Neuro Oncol 2009, 11:529-542

88. Ueda R, Fujita M, Zhu X, Sasaki K, Kastenhuber ER, Kohanbash G, McDonald HA, Harper J, Lonning S, Okada H: Systemic inhibition of transforming growth factor-beta in glioma-bearing mice improves the therapeutic efficacy of glioma-associated antigen peptide vaccines. Clin Cancer Res 2009, 15:6551-6559.

89. Derynck R, Akhurst RJ, Balmain A: TGF-beta signaling in tumor suppression and cancer progression. Nat Genet 2001, 29:117-129.

90. Chen ML, Pittet MJ, Gorelik L, Flavell RA, Weissleder R, von Boehmer H, Khazaie K: Regulatory T cells suppress tumor-specific CD8 T cell cytotoxicity through TGF-beta signals in vivo. Proc Natl Acad Sci U S A 2005, 102:419-424.

91. Fresno Vara JA, Casado E, de Castro J, Cejas P, Belda-Iniesta C, GonzalezBaron M: PI3K/Akt signalling pathway and cancer. Cancer Treat Rev 2004, 30:193-204.

92. Dong H, Strome SE, Salomao DR, Tamura H, Hirano F, Flies DB, Roche PC, Lu J, Zhu G, Tamada K, Lennon VA, Celis E, Chen L: Tumor-associated B7-H1 promotes T-cell apoptosis: a potential mechanism of immune evasion. Nat Med 2002, 8:793-800.

93. Rodrigues JC, Gonzalez GC, Zhang L, Ibrahim G, Kelly JJ, Gustafson MP, Lin $Y$, Dietz AB, Forsyth PA, Yong WW, Parney IF: Normal human monocytes 
exposed to glioma cells acquire myeloid-derived suppressor cell-like properties. Neuro Oncol 2010, 12:351-365.

94. Bloch O, Crane CA, Kaur R, Safaee M, Rutkowski MJ, Parsa AT: Gliomas Promote Immunosuppression through Induction of B7-H1 Expression in Tumor-Associated Macrophages. Clin Cancer Res 2013, 19:3165-3175.

95. Crane C, Panner A, Pieper RO, Arbiser J, Parsa AT: Honokiol-mediated inhibition of PI3K/mTOR pathway: a potential strategy to overcome immunoresistance in glioma, breast, and prostate carcinoma without impacting T cell function. J Immunother 2009, 32:585-592.

96. Wu A, Oh S, Wiesner SM, Ericson K, Chen L, Hall WA, Champoux PE, Low WC, Ohlfest JR: Persistence of CD133+ cells in human and mouse glioma cell lines: detailed characterization of GL261 glioma cells with cancer stem cell-like properties. Stem Cells Dev 2008, 17:173-184.

97. Pellegatta S, Poliani PL, Corno D, Menghi F, Ghielmetti F, Suarez-Merino B, Caldera V, Nava S, Ravanini M, Facchetti F, Bruzzone MG, Finocchiaro G: Neurospheres enriched in cancer stem-like cells are highly effective in eliciting a dendritic cell-mediated immune response against malignant gliomas. Cancer Res 2006, 66:10247-10252.

98. Xu M, Yao Y, Hua W, Wu Z, Zhong P, Mao Y, Zhou L, Luo F, Chu Y: Mouse glioma immunotherapy mediated by A2B5+ GL261 cell lysate-pulsed dendritic cells. J Neurooncol 2014, 116:497-504.

99. Crane CA, Ahn BJ, Han SJ, Parsa AT: Soluble factors secreted by glioblastoma cell lines facilitate recruitment, survival, and expansion of regulatory $T$ cells: implications for immunotherapy. Neuro Oncol 2012, 14:584-595.

100. Akbasak A, Oldfield EH, Saris SC: Expression and modulation of major histocompatibility antigens on murine primary brain tumor in vitro. J Neurosurg 1991, 75:922-929.

101. Prins RM, Odesa SK, Liau LM: Immunotherapeutic targeting of shared melanoma-associated antigens in a murine glioma model. Cancer Res 2003, 63:8487-8491.

102. Kim CH, Hong MJ, Park SD, Kim CK, Park MY, Sohn HJ, Cho HI, Kim TG, Hong YK: Enhancement of anti-tumor immunity specific to murine glioma by vaccination with tumor cell lysate-pulsed dendritic cells engineered to produce interleukin-12. Cancer Immunol Immunother 2006, 55:1309-1319.

103. Curtin JF, Candolfi M, Fakhouri TM, Liu C, Alden A, Edwards M, Lowenstein PR, Castro MG: Treg depletion inhibits efficacy of cancer immunotherapy: implications for clinical trials. PLoS One 2008, 3:e1983.

104. Park SD, Kim CH, Kim CK, Park JA, Sohn HJ, Hong YK, Kim TG: Cross-priming by temozolomide enhances antitumor immunity of dendritic cell vaccination in murine brain tumor model. Vaccine 2007, 25:3485-3491.

105. Kim TG, Kim CH, Park JS, Park SD, Kim CK, Chung DS, Hong YK: Immunological factors relating to the antitumor effect of temozolomide chemoimmunotherapy in a murine glioma model. Clin Vaccine Immunol 2010, 17:143-153.

106. Weiner NE, Pyles RB, Chalk CL, Balko MG, Miller MA, Dyer CA, Warnick RE Parysek LM: A syngeneic mouse glioma model for study of glioblastoma therapy. J Neuropathol Exp Neurol 1999, 58:54-60.

107. Dyer CA, Philibotte T: A clone of the MOCH-1 glial tumor in culture: multiple phenotypes expressed under different environmental conditions. J Neuropathol Exp Neurol 1995, 54:852-863.

108. Higgins RJ, McKisic M, Dickinson PJ, Jimenez DF, Dow SW, Tripp LD, LeCouteur RA: Growth inhibition of an orthotopic glioblastoma in immunocompetent mice by cationic lipid-DNA complexes. Cancer Immunol Immunother 2004, 53:338-344.

109. Hellums EK, Markert JM, Parker JN, He B, Perbal B, Roizman B, Whitley RJ, Langford CP, Bharara S, Gillespie GY: Increased efficacy of an interleukin-12secreting herpes simplex virus in a syngeneic intracranial murine glioma model. Neuro Oncol 2005, 7:213-224.

110. Markert JM, Cody JJ, Parker JN, Coleman JM, Price KH, Kern ER, Quenelle DC, Lakeman AD, Schoeb TR, Palmer CA, Cartner SC, Gillespie GY, Whitley RJ: Preclinical evaluation of a genetically engineered herpes simplex virus expressing interleukin-12. J Virol 2012, 86:5304-5313.

111. Newcomb EW, Zagzag D: The murine GL261 glioma experimental model to assess novel brain tumor treatments. In CNS Cancer: Models, Markers, Prognostic Factors, Targets and Therapeutic Approaches. Edited by Van Meir EG. New York: Springer; 2009:227-241.

112. De Vleeschouwer S, Fieuws S, Rutkowski S, Van Calenbergh F, Van Loon J, Goffin J, Sciot R, Wilms G, Demaerel P, Warmuth-Metz M, Soerensen N, Wolff JE, Wagner S, Kaempgen E, Van Gool SW: Postoperative adjuvant dendritic cell-based immunotherapy in patients with relapsed glioblastoma multiforme. Clin Cancer Res 2008, 14:3098-3104.
113. Sampson JH, Archer GE, Mitchell DA, Heimberger AB, Herndon JE 2nd, Lally-Goss D, McGehee-Norman S, Paolino A, Reardon DA, Friedman AH, Friedman HS, Bigner DD: An epidermal growth factor receptor variant III-targeted vaccine is safe and immunogenic in patients with glioblastoma multiforme. Mol Cancer Ther 2009, 8:2773-2779.

114. Sampson JH, Archer GE, Mitchell DA, Heimberger AB, Bigner DD: Tumorspecific immunotherapy targeting the EGFRvIll mutation in patients with malignant glioma. Semin Immunol 2008, 20:267-275.

115. Neninger Vinageras E, de la Torre A, Osorio Rodriguez M, Catala Ferrer M, Bravo I, del Pino Mendoza M, Abreu Abreu D, Acosta Brooks S, Rives R, del Castillo Carrillo C, González Dueñas M, Viada C, García Verdecia B, Crombet Ramos T, González Marinello G, Lage Dávila A: Phase II randomized controlled trial of an epidermal growth factor vaccine in advanced non-small-cell lung cancer. J Clin Oncol 2008, 26:1452-1458.

116. Saito R, Mizuno M, Nakahara N, Tsuno T, Kumabe T, Yoshimoto T, Yoshida J: Vaccination with tumor cell lysate-pulsed dendritic cells augments the effect of IFN-beta gene therapy for malignant glioma in an experimental mouse intracranial glioma. Int J Cancer 2004, 111:777-782.

117. Tsugawa T, Kuwashima N, Sato H, Fellows-Mayle WK, Dusak JE, Okada K, Papworth GD, Watkins SC, Gambotto A, Yoshida J, Pollack IF, Okada H: Sequential delivery of interferon-alpha gene and DCs to intracranial gliomas promotes an effective antitumor response. Gene Ther 2004, 11:1551-1558.

118. Kuwashima N, Nishimura F, Eguchi J, Sato H, Hatano M, Tsugawa T, Sakaida T, Dusak JE, Fellows-Mayle WK, Papworth GD, Watkins SC, Gambotto A Pollack IF, Storkus WJ, Okada H: Delivery of dendritic cells engineered to secrete IFN-alpha into central nervous system tumors enhances the efficacy of peripheral tumor cell vaccines: dependence on apoptotic pathways. J Immunol 2005, 175:2730-2740.

119. Heimberger AB, Crotty LE, Archer GE, Hess KR, Wikstrand CJ, Friedman AH, Friedman HS, Bigner DD, Sampson JH: Epidermal growth factor receptor VIII peptide vaccination is efficacious against established intracerebral tumors. Clin Cancer Res 2003, 9:4247-4254.

120. Hau $P$, Jachimczak $P$, Schlingensiepen $R$, Schulmeyer $F$, Jauch $T$, Steinbrecher A, Brawanski A, Proescholdt M, Schlaier J, Buchroithner J, Pichler J, Wurm G, Mehdorn M, Strege R, Schuierer G, Villarrubia V, Fellner F, Jansen O, Straube T, Nohria V, Goldbrunner M, Kunst M, Schmaus S, Stauder G, Bogdahn U, Schlingensiepen KH: Inhibition of TGF-beta2 with AP 12009 in recurrent malignant gliomas: from preclinical to phase I/II studies. Oligonucleotides 2007, 17:201-212.

121. Jaschinski F, Rothhammer $T$, Jachimczak P, Seitz C, Schneider A, Schlingensiepen $\mathrm{KH}$ : The antisense oligonucleotide trabedersen (AP 12009) for the targeted inhibition of TGF-beta2. Curr Pharm Biotechnol 2011, 12:2203-2213.

122. Chiocca EA, Smith KM, McKinney B, Palmer CA, Rosenfeld S, Lillehei K, Hamilton A, DeMasters BK, Judy K, Kirn D: A phase I trial of Ad.hIFN-beta gene therapy for glioma. Mol Ther 2008, 16:618-626.

123. Uhl M, Aulwurm S, Wischhusen J, Weiler M, Ma JY, Almirez R, Mangadu R, Liu YW, Platten M, Herrlinger U, Murphy A, Wong DH, Wick W, Higgins LS, Weller M: SD-208, a novel transforming growth factor beta receptor I kinase inhibitor, inhibits growth and invasiveness and enhances immunogenicity of murine and human glioma cells in vitro and in vivo. Cancer Res 2004, 64:7954-7961.

124. Spagnolo A, Glick RP, Lin H, Cohen EP, Feinstein DL, Lichtor T: Prolonged survival of mice with established intracerebral glioma receiving combined treatment with peroxisome proliferator-activated receptorgamma thiazolidinedione agonists and interleukin-2-secreting syngeneic/allogeneic fibroblasts. J Neurosurg 2007, 106:299-305.

125. Natsume A, Mizuno M, Ryuke Y, Yoshida J: Antitumor effect and cellular immunity activation by murine interferon-beta gene transfer against intracerebral glioma in mouse. Gene Ther 1999, 6:1626-1633.

\section{doi:10.1186/1479-5876-12-107}

Cite this article as: Oh et al:: Immunocompetent murine models for the study of glioblastoma immunotherapy. Journal of Translational Medicine 2014 12:107. 